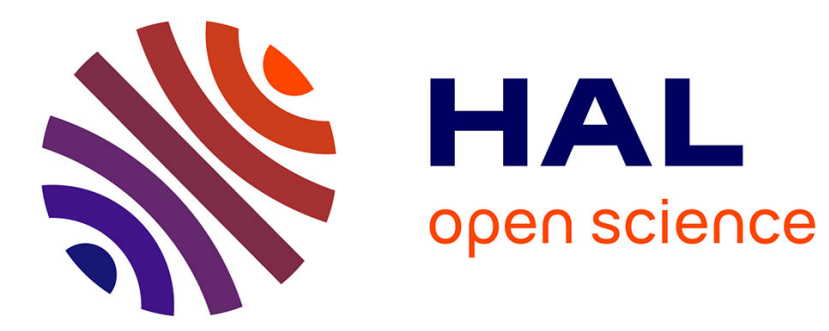

\title{
Local farmers' organisations: a space for peer-to-peer learning? The case of milk collection cooperatives in Morocco
}

Nicolas Faysse, M.T. Sraïri, Mostafa Errahj

\section{To cite this version:}

Nicolas Faysse, M.T. Sraïri, Mostafa Errahj. Local farmers' organisations: a space for peer-to-peer learning? The case of milk collection cooperatives in Morocco. Journal of Agricultural Education and Extension, 2012, pp.285-299. cirad-00903206

\section{HAL Id: cirad-00903206 http://hal.cirad.fr/cirad-00903206}

Submitted on 10 Nov 2013

HAL is a multi-disciplinary open access archive for the deposit and dissemination of scientific research documents, whether they are published or not. The documents may come from teaching and research institutions in France or abroad, or from public or private research centers.
L'archive ouverte pluridisciplinaire HAL, est destinée au dépôt et à la diffusion de documents scientifiques de niveau recherche, publiés ou non, émanant des établissements d'enseignement et de recherche français ou étrangers, des laboratoires publics ou privés. 


\title{
Local farmers' organisations: a space for peer-to-peer learning? The case of milk collection cooperatives in Morocco
}

\author{
Nicolas Faysse ${ }^{\mathrm{a}}$, Mohamed Taher Sraïri ${ }^{\mathrm{b}}$, Mostafa Errahj ${ }^{\mathrm{c}}$
}

\footnotetext{
a (corresponding author) CIRAD, G-EAU Research Unit, National Agricultural College of Meknès. faysse@cirad.fr, Tel: 002126744582 46, Fax: 00212535300238.

${ }^{\mathrm{b}}$ Department of Animal Production, Hassan II Institute of Agronomy and Veterinary Medicine, BP 6202, 10101, Rabat-Instituts, Rabat, Morocco. tsrairi@yahoo.fr.

${ }^{\mathrm{c}}$ National Agricultural College of Meknès, km 10, Haj Kaddour Road, BP S/40 Meknès, Morocco. merrahj@gmail.com.
}

This is an Author's Accepted Manuscript of an article published in the Journal of Agricultural Education and Extension, May 2012 [copyright Taylor \& Francis], available online at: http://www.tandfonline.com/doi/abs/10.1080/1389224X.2012.670053.

\section{ABSTRACT.}

Purpose. The study investigated to what extent local farmers' organisations are spaces where farmers discuss, learn, and innovate.

Design/methodology/approach. Two milk collection cooperatives in Morocco were studied. The study analysed the discussion networks, their impacts on farmers' knowledge and innovation, and the performance of collective action at cooperative level.

Findings. In both cooperatives, only two-thirds of the farmers regularly discussed dairy practices with other farmers. Most leaders of one cooperative were acknowledged to be experienced farmers and played key roles as advisors on dairy farming. Farmers' involvement in dialogue networks in this cooperative improved their capacity to innovate in dairy farming, even though their knowledge on some issues related to cattle health and nutrition was not improved. In the other cooperative, experienced farmers did not share their knowledge and farmers' involvement in dialogue networks at cooperative level had no impact on their knowledge and practices. Dialogue networks and collective action were found to influence each other, since in the first cooperative, collective action was considered by members to be efficient, whereas in the second collective action was limited to milk collection.

Practical implications. The study enabled identification of stumbling blocks which need to be addressed to get local farmers' organisations involved in farmer capacity building.

Originality/value. While the importance of local discussion networks for knowledge creation and diffusion is widely acknowledged, taking such networks into account in farmers' capacity building programmes in developing countries has been hindered by their informality. Combining the analysis of dialogue networks and collective action proved to be a productive way to assess the potentialities of working with farmers' organisations with the aim of establishing a connection with local discussion networks.

Paper type. Original study.

Key words: Dairy farming - Discussion network - Farmers' organisation - Morocco. 


\section{Introduction}

In the past 20 years, many innovative approaches have been designed for small-scale farmers' capacity building in developing countries in terms of both institutional set-ups and methods. These approaches, which were mainly built on the criticism of the transfer of the technology model, highlighted farmers' knowledge and attempted to involve them in multi-stakeholder partnerships for local innovation and in capacity-building processes (Hall, 2009).

Yet studies of these experimental approaches identified two largely unresolved challenges. First, many of the institutional set-ups have not succeeded in involving farmers as empowered partners in innovation processes (Scoones and Thompson, 2009). Second, many studies underlined the importance of social networks for farmers' learning, and in particular peer-to-peer communication within farmers groups (e.g., Matuschke, 2008) and concluded that such networks and local social structures should be taken into account when designing activities aimed at supporting such learning (Hoang et al., 2006). For instance, activities could be organised with farmers who belong to the same discussion networks (Darré, 1996) and could specifically involve the farmers who are sought after for advice (Isaac et al., 2007). However, this recommendation has seldom been put into practice, since discussion networks are usually informal and are consequently not easy to identify. To get around this difficulty, some approaches for farmer capacity building at group level have involved the creation of specific farmer groups aimed at building new discussion networks. This approach has been used in farmers' research groups (Sanginga et al., 2006) and farmer field schools (Tin et al., 2010). However, it requires considerable financial and human capacities, and large-scale implementation may be difficult when the budget for extension activities is limited.

Local farmers' organisations have flourished in recent years, in particular in providing services to their members and in natural resources management (Mercoiret et al., 2006; Pretty and Ward, 2001). Organising farmer capacity building in partnership with existing local farmers' organisations may be a way to address both the above-mentioned problems of farmer empowerment and the need for connections with farmer dialogue networks. Indeed, local farmers' organisations may be able to interact with farmers' discussion networks more easily than entities that are external to the local communities, and are mostly only infrequently involved. In recent years, the involvement of farmers' organisations in capacity-building activities has been considered to be increasingly important (Heemskerk et al., 2008). According to Mercoiret et al. (2006), farmers' organisations can support farmer capacity building and innovation processes in three main ways: (1) as a space for exchange to consolidate and disseminate farmers' know-how and innovations developed by the farmers themselves; (2) by setting up specific support mechanisms, often with external funding; (3) by participating in the definition and monitoring of the activities of research and extension organisations. In addition, in the case of limited funding, the involvement of farmers' organisations could facilitate cost effective implementation of capacity-building activities at a large scale.

Local farmers' organisations have generally become involved in knowledge management and innovation within the framework of an institutional set-up with external support from a regional federation of farmers' organisations (Moumouni et al., 2009; Wennink and Heemskerck, 2006), a national government (Cristóvão and Perreira, 2004), or international cooperation (Perez et al., 2009). However, these authors assessed the way farmers' organisations interact with other organisations in the framework of specific support programmes and their impacts in terms of knowledge access and innovation. Their studies did not include detailed analyses of the interaction between local discussion networks and farmers' organisations outside the framework of a specific programme. Yet, relations between local farmers' organisations (which are usually created to provide services to their members), and discussion networks are not obvious. Assessing such relations and the possible stumbling blocks to the efficacy of discussion networks connected to farmers' organisations should help design programmes involving farmers' organisations in capacity building based on local dynamics, and which specifically address these stumbling blocks.

In this article, we analyse to what extent local farmers' organisations are spaces where farmers talk to each other about agricultural practices, and obtain the information they need to address problems related to their own farming practices. Discussion networks related to farming activities, their impacts, and their links with collective actions were studied in two Moroccan milk collection cooperatives. In Morocco, the State was responsible for extension activities until the 1990s, when they withdrew. In 
2008, a "Green Morocco" Plan was enacted that put agriculture back at the top of the political agenda. In this context, the government started thinking about how the State could again start supporting extension activities, which were to be contracted out to non-governmental entities. Although these ambitions were clearly announced, after two decades of institutional silence, the ways and means to achieve them are less clear, especially in the smallholder sector, which still represents more than $80 \%$ of farms in Morocco.

\section{Conceptual framework}

Initial studies of the processes involved in farmers' learning and in farmers' changing their practices, such as the influential work of Rogers (1995), mostly focused on the diffusion of innovations designed outside farmers' groups. In such linear models of innovation diffusion, farmers' social networks generally only played a role in conveying information. In particular, applying Granovetter's (1973) hypothesis concerning the "strength of weak ties", Rogers (1995) postulated that the potential of communication networks for diffusion of innovation increases if such networks include farmers who are not related to the others through day-to-day social interactions. These networks may be even more efficient in disseminating innovations if they include farmers who have already implemented the innovations concerned (Valente, 1996). In such networks, the different types of knowledge concerning a specific activity may not be shared in the same way among farmers. Wyckhuys and O'Neil (2007) showed that in farmer-to-farmer discussions regarding pest management, information on certain technologies were shared among farmers, but not other information that some of them had learnt during training activities. Discussion may not even be necessary since imitation may play an important role in innovation diffusion (Pomp and Burger, 1995).

Other authors considered farmers' networks not only as channels for information dissemination, but also as spaces for the negotiation of innovations, where actors attempt to enrol others in the implementation of an innovation (Callon, 1986), and as spaces for the creation of knowledge (Leeuwis and van den Ban, 2004). According to Darré (1996), farmers define local norms in group-based dialogue networks. For a specific issue, each norm defines the set of alternatives considered to be appropriate in the area in which the farmers live. These different definitions of farmers' networks should not be seen as mutually exclusive but as providing complementary analytical viewpoints. The concept of networks as spaces for knowledge creation had a wide-ranging impact on both extension approaches (such as farmer field schools) and on the way external organisations, and especially NGOs, support farmers' design and implementation of innovations at local level (Sanginga et al., 2009).

To assess farmers' interactions both within and outside farmers' groups, studies have mainly relied on social network analysis, which focuses on a finite set of actors and the relations between them (Wasserman and Faust, 1994). First, some authors characterised the different types of networks in which farmers are involved (mainly day-to-day communication, advice seeking and collective action) and looked for possible links between them. Advice-seeking networks may differ from wider social links based on day-to-day interactions between neighbours and on social proximity (Chiffoleau, 2005; Isaac et al., 2007). These networks may involve farmers who belong to the same community, but also farmers located farther away as well as actors of the agricultural sector who are not farmers. Second, social network analyses assessed the relation between farmers' attributes and the characteristics of farmers' networks. This relation was characterised in two ways: farmers may be part of a network because they share certain characteristics, but being part of a network and/or sharing the characteristics of such a network may also have an impact on the farmers themselves, and in some cases it may not be possible to argue a specific causal relationship (Matuschke, 2008). The efficiency of dialogue networks can be measured by looking for a correlation between belonging to a network and having gained some information (Van der Broeck and Dercon, 2011) or having implemented an innovation (Darr and Pretzsch, 2008).

Collective action can be defined as "action taken by a group (either directly or on its behalf through an organisation) in pursuit of members' perceived shared interests" (Marshall, 1998). Farmers' organisations should not be equated with collective action, but rather seen as structures where collective action may take place. In analysing collective action in rural areas, quantitative and qualitative methods can complement each other (Meinzen-Dick et al., 2004). Analysis of the 
performance of collective action can be based on technical and economic data (e.g. the quality of service delivery or the profitability of the cooperative) and the farmers' own assessment of the performance of the farmers' organisation. This assessment can cover different aspects of collective action, such as the quality and competitiveness of the services provided, the efficiency of management or the equity of the governance structure (Shah, 1996). In assessing a large set of farmers' organisations in India, Shah (1996) found that successful farmers' organisations are able to diversify the type of services they provide to their members, so as to remain central in the daily life of the latter.

While extensive literature exists on the way collective action is embedded in social networks (e.g., Diani and McAdam, 2003), fewer authors have studied the links between collective action and networks for knowledge diffusion. Their analyses were performed in two ways: first, Crona and Bodin (2006) analysed networks for knowledge communication using groups of people acting collectively as units of analysis. They showed how fishermen's groups organised around different fishing techniques may have different knowledge patterns. Second, using econometric analysis, Eklund et al. (2007) studied the impact of the performance of collective action on knowledge diffusion. Higher management performance in women's associations was found to have a positive impact on knowledge diffusion. However, to our knowledge, there has been no study of networks for knowledge communication within local farmers' organisations combining social network analysis with an assessment of the performance of collective action within the farmers' organisation.

\section{Research setting}

\section{Method and data collection}

To assess to what extent dairy cooperatives are spaces where farmers talk to each other and improve their knowledge about dairy farming, we investigated the discussion networks themselves, their impacts, and finally, collective action at cooperative level. First, we wanted to know whether the discussion networks in which the members of the cooperative were involved functioned within the framework of the cooperative considered as a physical space (i.e. did the members of the cooperative meet at the cooperative compound to discuss dairy practices?) and as a group (i.e. did the members of the cooperative actually talk with other members about dairy practices?). We also wanted to know whether the farmers who were considered to be innovators in the villages in which the cooperatives were located were members of the cooperatives and of the dialogue networks. Second, we assessed the efficiency of the discussion networks in the cooperatives by analysing whether members' participation in the networks led to improved knowledge and innovation in dairy practices (it was impossible to measure the impact of farmers' knowledge on dairy performance because of the high variability in the genetic composition of the herds). Third, we analysed the members' assessment of the performance of collective action within the cooperative and to what extent the collective action improved dairy knowledge and practices. The analysis therefore encompassed both farmers and the cooperative levels.

A survey of the two cooperatives (cooperatives A and B) was conducted in 2008. A total of 138 farmers were interviewed in cooperative $\mathrm{A}$ and 51 farmers in cooperative $\mathrm{B}$, representing respectively $96 \%$ and $87 \%$ of the members who delivered milk to the cooperative.

First, the dialogue networks were characterised. Farmers were asked where dairy-related discussions took place. They were then asked if they discussed dairy practices with other farmers, and, if so, they were asked to identify the farmers concerned (whether they were members of the cooperative or not), i.e. their interlocutors with regards dairy farming. Since preliminary interviews revealed that a non-negligible number of cooperative members did not discuss dairy practices, the analysis focused on the difference between farmers who did not interact and farmers who did, and, as long as the exchange occurred regularly, discussions on a day-to-day basis and specific advice-seeking forms of dialogue on dairy farming were not distinguished in the way the questions were framed.

Following Darré's (1991) approach, we identified discussion networks by focusing on on-going debates among farmers regarding dairy farming, which revolve around the unstable parts of the local norms. This enabled farmers to choose among the many farmers they discussed with on a day-to-day basis, those with whom they specifically discussed dairy farming. Farmers were invited to name the other farmers with whom they discussed an on-going innovation, e.g. an innovation which had not yet 
reached consensus in the community. In each cooperative, the innovation chosen was the most important innovation in dairy farming at the time of the survey. The innovations were lucerne in cooperative A and silage maize in cooperative B. If the farmer did not identify any other farmers with whom he discussed these innovations, the question was extended to include other possible innovations related to dairy practices. Farmers were also asked to name the main innovators in dairy farming in their village (including farmers who did not belong to the cooperative). The network of farmers cited by members as interlocutors was then depicted using Netdraw (Borgatti, 2002).

Second, farmers were asked: i) about their knowledge regarding the causes, prevention and cures for the most common cattle diseases in the study area (theileriosis, babesiosis and mastitis); ii) their knowledge about watering; and iii) if they themselves had implemented any innovations in the past 10 years. The impacts of members' participation in cooperative discussion networks concerning their knowledge of dairy farming were assessed by selecting aspects of the three cattle diseases about which not all farmers had the necessary information. A Pearson Chi 2 test was used to check for statistically significant correlations between being part of the cooperative discussion network and having such information. The same test was used to look for a correlation between belonging to the cooperative discussion network and having implemented an innovation in dairy farming in the past 10 years.

Third, the Likert scale was used to assess the farmers' perceptions of the performance of collective action at cooperative level. The scale was based on a set of 16 items comprising four items for each of the following themes: (1) services and competitiveness compared to other cooperatives and private milk collectors; (2) management; (3) appropriation by members; and (4) integration of the cooperative in local communities. Farmers were asked to state whether they agreed or disagreed with or had no opinion on each of the items. The actions by the cooperatives in support of dairy farming were also assessed.

This quantitative assessment of collective action was supplemented by qualitative interviews with leaders and with grassroots members on dairy practices and communication networks. Sixteen of the respondents in cooperative A and three in cooperative B were women (almost all formal members of cooperatives are men). However, the study did not include possible discussion networks among women, because, when questioned, they gave the names of farmers with whom their husbands were in touch. Besides, the innovations considered (lucerne, silage maize) were part of the men's responsibilities rather than the women's.

\section{Case studies}

In Morocco, the dairy farming sector mainly depends on smallholder farmers (Sraïri et al., 2009), who are grouped in local cooperatives to which they deliver their milk once or twice a day. Milk delivered to the local cooperative is then collected by the dairy processing plants. Smallholder dairy farming in irrigated areas of Morocco, which accounts for more than 50\% of the milk processed in the country, is somewhat different from that in other developing countries as it has incorporated many aspects of intensive dairy cattle production, such as the use of specialised breeds (Holstein and Montbéliarde), crosses with local breeds, and the widespread use of concentrates as feed.

The two cooperatives analysed here are located in the Gharb Region. In this region, cows are generally managed under a "zero grazing" system, i.e. they spend the whole year in the cowshed. This practice can be explained by the lack of available pastures, since the cattle load is generally high and arable land is primarily used to grow cereals or crops other than forage. Cowsheds are located close to the home and both are protected from outside view by high walls. Outsiders can only enter and see the cows if they are explicitly invited to do so by the family. Farmers explain that this is because they want to avoid envy, black magic and robbery, and because women take care of the cows. Consequently, farmers may not be aware of all the details concerning their neighbours' dairy farming practices (for example the type and the amount of concentrates used in the feed) or of their dairy performances. Information concerning dairy farming practices in the cowshed circulates via the discussion networks rather than "over the fence".

The two cooperatives were chosen because of their medium performance. They performed well compared to other milk collection cooperatives in the Gharb Region. In particular, they had introduced milk quality control in the form of compulsory delivery of milk twice a day during hot weather, they paid farmer members on time, and general assemblies were held once a year, none of these activities 
being common in other cooperatives in the region. On the other hand, they did not provide any other services to their members, and in that sense were much less active than milk collection cooperatives in other regions such as Tadla or Souss (Faysse et al., 2010).

Cooperative A was created in 2006, when a group of farmers decided to split from an existing cooperative in the same village, because there was no milk quality control and no accounting transparency. All members of cooperative A took an oath not to cheat on milk quality. In 2008, the cooperative officially had 180 members, 143 of whom were delivering the milk at the time of the survey. In the past, farmers who belonged to cooperative A had grown sugar beet and cash crops. In 2005, production of sugar beet was stopped and marketing of cash crops became difficult, so farmers decided to shift to cattle farming as their main source of income. Several farmers testified that "now, the only project in our community is cattle farming". Cooperative B was created in 1984 and in 2008 officially had 140 members, although only 70 farmers delivered milk to the cooperative, and 12 other farmers delivered milk even though they were not members. Cooperative A had more than twice as many members who delivered milk than cooperative B, but further enquiries revealed that the average milk production per cow in the two cooperatives was similar (Khlifi, 2008).

\section{Results}

\section{Dairy discussion networks and involvement of innovators}

Farmers said that discussions took place in the places where farmers generally socialise, i.e. coffee shops or around the mosque (Table 1). The milk-collection compound of the cooperative was mentioned, but did not appear to be a preferred place for discussion and, in any case, rather than going themselves, many farmers send their sons to deliver milk to the cooperative. Moreover, the compound belonging to cooperative A was located in the village and farmers often passed by, but the compound had only started operating four months before the survey was held (previously, farmers who belonged to cooperative A delivered milk to a rented compound located on the outskirts of the village). In contrast, in cooperative B, the compound was located in an unpopulated area between the villages which delivered to the cooperative. Consequently, the farmers never passed by for any other reason than delivering milk or getting paid once every two weeks.

Table 1. Places where cooperative members discuss dairy practices $(\%)$.

\begin{tabular}{|c|c|c|c|c|c|c|c|}
\hline & $\begin{array}{l}\text { Cooperative } \\
\text { compound }\end{array}$ & Mosque & $\begin{array}{l}\text { In the field or } \\
\text { on the road }\end{array}$ & $\begin{array}{l}\text { Coffee- } \\
\text { house }\end{array}$ & Shops & Others & $\begin{array}{l}\text { No } \\
\text { discussions } \\
\text { outside the } \\
\text { house }\end{array}$ \\
\hline Coop. A & 22 & 17 & 35 & 22 & 9 & 6 & 37 \\
\hline Coop. B & 35 & 8 & 16 & 20 & 14 & 10 & 26 \\
\hline
\end{tabular}

In both cooperatives, around $30 \%$ of the farmers who were interviewed said they did not discuss cattle farming with other farmers. Dairy farming was generally considered to be a private affair. In addition, some farmers saw no advantage in discussing dairy activities, because they believed that, given their land and cattle, they would not be able to improve their dairy farming. In both cooperatives, the remaining $70 \%$ of farmers who discussed dairy practices with other farmers said the people they talked to were from the same village or from a neighbouring village. Among farmers belonging to cooperative A who named another farmer, $72 \%$ cited at least one member of the cooperative. Other farmers who were cited were members of the older cooperative. In cooperative B, the percentage of farmers who cited at least one cooperative member. dropped to $52 \%$. In this cooperative, the many farmers cited who were not members of the cooperative delivered their milk to private buyers. In both cases, $40 \%$ of farmers who cited anyone cited only members of the cooperative.

Figure 1 shows the cooperative members who were cited as farmers' interlocutors with regards to dairy farming in cooperatives $\mathrm{A}$ and $\mathrm{B}$. The relations are asymmetrical, i.e. there were only two 
reciprocal links in cooperative $\mathrm{A}$ and one in cooperative $\mathrm{B}$, implying that farmers mentioned many more advice-seeking relations than reciprocal discussions. Thus from now on, we use the expression "advice-seeking relations". The density of each advice-seeking network among members of the cooperative (i.e., the ratio between existing ties and the total number of possible ties within the network) was calculated taking into account the direction of the relations. The density was 0.0035 for cooperative A and 0.0056 for cooperative B. These densities, which mean an average of 0,48 link per farmer in cooperative A (resp. 0,28 in cooperative B), are low. In comparison, Chiffoleau (2006) found a density of 0.62 for the advice network of a smaller 32-farmer group, and Saurabh (2009) measured a density of 0.0025 for the directed discussion network of a group of similar size (109 members), a density that she also describes as low compared to the more intense discussions that group members had with persons outside the group.

Table 2. Farmers cited by cooperative members at least four times either as interlocutors or as innovators.

\begin{tabular}{|c|c|c|c|c|c|c|c|c|c|c|}
\hline & \multicolumn{5}{|c|}{ Cooperative A } & \multicolumn{5}{|c|}{ Cooperative B } \\
\hline Farmer & A3 & A53 & A62 & A75 & A90 & A144 & B27 & B77 & $\mathrm{BA}$ & $\mathrm{BB}$ \\
\hline $\begin{array}{l}\text { Number of times cited as being } \\
\text { involved in dialogue networks }\end{array}$ & 17 & 5 & 17 & 5 & 6 & 1 & 0 & 0 & 3 & 1 \\
\hline $\begin{array}{l}\text { Number of times cited as } \\
\text { innovator }\end{array}$ & 10 & 0 & 26 & 1 & 0 & 7 & 6 & 4 & 31 & 9 \\
\hline
\end{tabular}

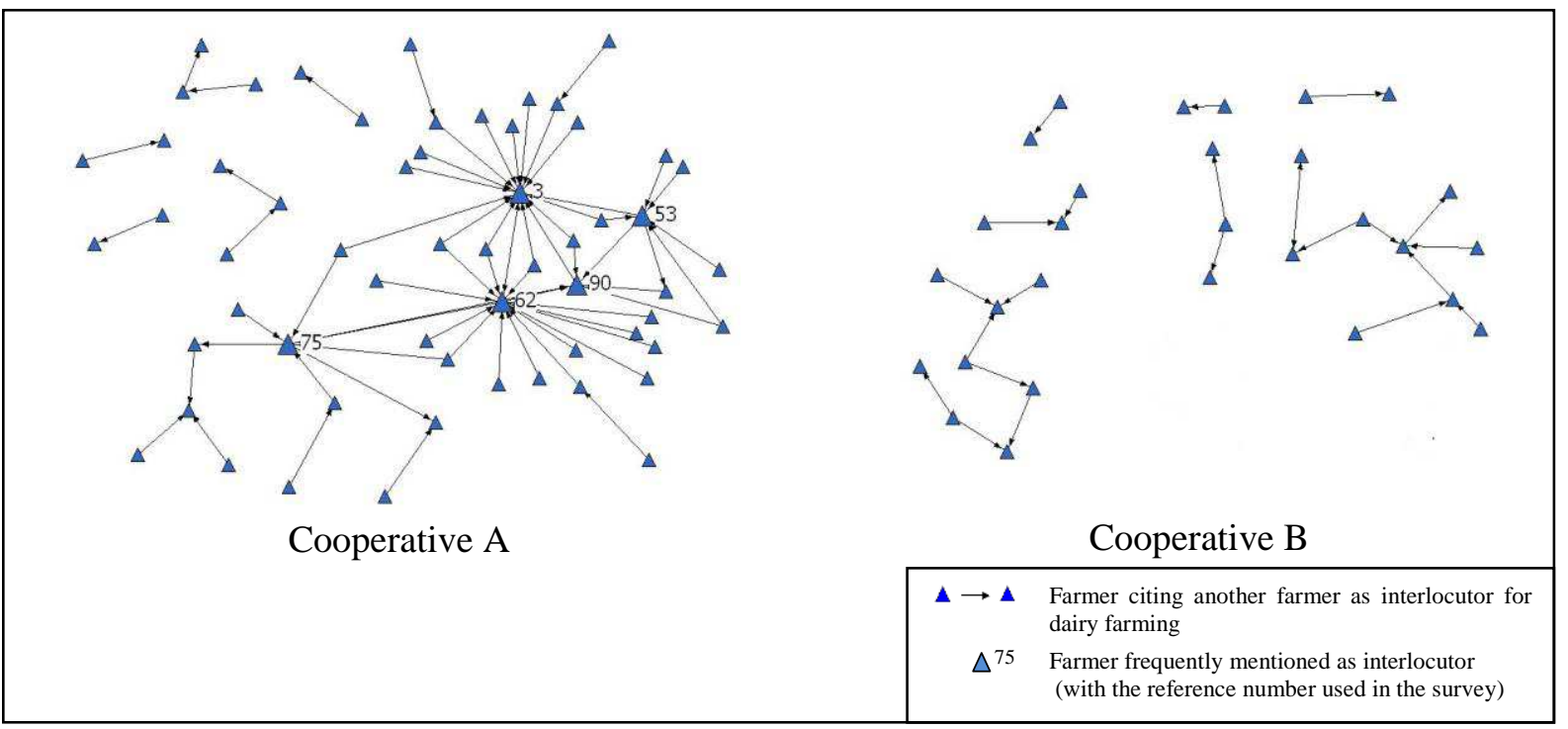

Figure 1. Discussion networks with regards dairy farming among cooperative members of cooperatives A and B.

Table 2 lists farmers who were cited at least four times either as interlocutors for dairy farming or as innovators in dairy farming practices (whether or not they belonged to the cooperative). In cooperative A, the five most frequently cited interlocutors were members of the cooperative, met very often, and included the two most often cited innovators (farmers A3 and A62). Reciprocal relations appeared between A3 and A62 and between A62 and A90. Farmer A3 was a cousin of the president of the cooperative; farmer A75 was the secretary of the cooperative, owned a retail outlet for feed concentrate and played a key role in the day-to-day management of the cooperative. Farmers A53 and A90 (who were not cited as innovators) acted as intermediaries between this core group and their own 
extended families. Farmer A144 was cited as an innovator but not as part of dialogue network: he was a young farmer, who was seen as somebody who always tried out new techniques, but was not really integrated in the village social networks. The main group in cooperative A formed a core periphery structure, with a group of farmers who were highly sought after and who themselves were closely interlinked, and a group of farmers in peripheral positions with minimum connections among themselves and who were rarely sought after by others (Borgatti and Everett, 1999).

Discussion networks in cooperative B were structured in unconnected local cliques (it should be borne in mind that these cliques may be interconnected through village dwellers who were not members of the cooperative). The most frequently cited interlocutors were only cited three times each, much less often than in cooperative A. Farmers in cooperative B cited four main innovators, two of whom were members of the cooperative. The two other farmers (referred to here as BA and BB) were the most often cited innovators. They were large-scale farmers who lived in the same villages as the members of the cooperative but did not belong to the cooperative. Each of these two farmers owned more than 20 cows and their milk was collected directly from their farm by the dairy processing plant. These two farms were registered in the dairy herd improvement programme, which means that technicians frequently visited them to monitor their dairy performance, and to give advice. The four farmers cited as innovators were almost never mentioned as taking part in discussion networks. Farmers who belonged to cooperative B said that they were not allowed to visit farmers BA's and BB's farms to see their cows or observe their dairy practices.

\section{Impacts of participation in discussion networks at cooperative level}

In both cooperatives, farmers' knowledge differed on the cause of transmission of theileriosis and babesiosis, on the reasons for the appearance of mastitis and the need to provide water ad libitum. For each of these items, Table 3 shows whether there was a correlation between having this information and being part of the cooperative advice-seeking network. Participation in the networks had no statistically measurable impact on any of these items in either of the cooperatives. Further interviews were conducted to understand the absence of a correlation with members of the main discussion network in cooperative A. These farmers explained that they did not ask the resource people any questions concerning theileriosis, babesiosis, mastitis or watering. Farmers did not perceive water distribution as an important issue that needed to be discussed. Concerning the cattle diseases, some farmers said they did not know it was possible to prevent diseases occurring, while others said that the main resource person for disease management was the vet.

Table 3. Correlation between cooperative members' participation in dialogue networks and the farmer's knowledge and innovations regarding dairy farming

\begin{tabular}{|c|c|c|c|c|}
\hline & THEIL & MAST & WATER & INNOV \\
\hline $\begin{array}{l}\text { Participation in dialogue } \\
\text { networks in coop. A }\end{array}$ & $-0.013(0.88)$ & $0.121(0.13)$ & $0.078(0.36)$ & $0.177(0.04)$ \\
\hline $\begin{array}{l}\text { Participation in dialogue } \\
\text { networks in coop. B }\end{array}$ & $0.116(0.42)$ & $0.048(0.74)$ & $0.116(0.42)$ & $0.203(0.15)$ \\
\hline
\end{tabular}

In cooperative A, $65 \%$ of the farmers interviewed had introduced innovations in cattle farming in the past 10 years. Among these farmers, innovations were mainly new forage crops and maize silage (78\% of respondents), using new types of concentrates to feed their cows (17\%) and milking machines (22\%). In cooperative B, $46 \%$ of the farmers interviewed had innovated. Their innovations were 
mainly new forage crops and silage (71\%), building new cowsheds (25\%) and using new types of concentrates (12\%). In cooperative B, seeking advice had no impact on whether the farmers introduced innovations or not (Table 3). By contrast, in cooperative A, farmers who sought advice innovated more than farmers who did not seek advice.

\section{Collective action at cooperative level}

Farmers' attitudes towards their cooperative were ranked according to farmers' answers to the Likert scale items. In cooperative A (resp. cooperative B), 65\% of farmers (resp. 39\%) showed a positive attitude, 33\% (resp. 47\%) a neutral attitude and 2\% (resp. 14\%) a negative attitude. Such results revealed a highly significant difference between the two cooperatives (khi2 of 15 meaningful at 5\%): farmers who belonged to cooperative A had a more positive attitude towards their cooperative than farmers who belonged to cooperative B. Indeed, cooperative A enjoyed sound financial management: it succeeded in building a compound using the profits earned only two years after its establishment. In contrast, cooperative B had not changed much since it was set up. All the money received from the dairy plant was distributed among the farmers twice a month, so that the cooperative's bank account was always empty. Many farmers claimed they had no confidence in the way the accounts were managed or in the fairness of distribution of the profits.

There were also differences in the way the two cooperatives supported dairy activities. In cooperative A, 50 pure-bred cows were imported between 2006 and 2008. The cooperative purchased milking machines and made enquiries about machines to crush the cattle feed. However, these collective actions by cooperative A did not include capacity-building activities. The involvement of cooperative B in dairy activities was much more limited. In particular, during the same period (20062008), only two large-scale farmers imported cows through the cooperative.

\section{Discussion}

Some links appeared between the three analyses of discussion networks, their impacts on knowledge and practices, and collective action at cooperative level. First, two factors help explain the difference between the two cooperatives concerning a link between being part of a discussion network and innovating. Recognised innovators were members of cooperative A, and these farmers were frequently cited as resource persons, while fewer innovators belonged to cooperative $\mathrm{B}$, and these innovators were not cited as such. In addition, cooperative A supported certain innovations, such as milking machines, whereas cooperative B did not support any innovations. Second, farmers belonging to the two cooperatives did not specifically benefit from their involvement in advice-seeking networks in their cooperatives to get information on cattle health and water. This implies that some of these farmers had access to other people to get information on these issues, namely farmers who did not belong to the cooperatives and vets.

Third, in the two case studies, collective action and the discussion networks had a reciprocal influence. In cooperative A, the network existed before the cooperative was created: the group of farmers already organised around the main leaders decided to leave the existing cooperative all at the same time. In cooperative B, the lack of successful collective action within the cooperative had an impact on the farmers' willingness to invest in dairy activities and therefore also in dialogue networks.

After the study, dairy farming workshops were organised in both cooperatives (Layadi et al., forthcoming). A vet and a specialist in cattle nutrition took part in discussions on cattle farming with the farmers. The workshops were organised in cooperation with the management committees of the cooperatives, who were responsible for inviting the farmers to take part. The management committee of cooperative A actively participated in organising the workshops, and participation increased from 25 farmers at the first workshop to around 60 at the last. The management committee of cooperative B was much less involved. Only 10 farmers attended the first workshop, and the number of participants subsequently decreased. Interviews conducted at the time of these workshops and the analysis described above help explain the different results. Cooperative A was already involved in improving cattle farming, since leaders in the cooperative played a central role in the networks that provided 
advice. Moreover, the management committee of the cooperative had the approval of the members of the cooperative. These elements gave the management committee the legitimacy to organise this type of workshop. In such a context, the workshops represented an opportunity for farmers to obtain more advanced knowledge about dairy farming, i.e., following Rogers (1995), to forge weak links with people outside the community with different knowledge of dairy farming. In cooperative B, members of the management committee were less interested in organising the workshops; in addition, its members did not believe the committee had the legitimacy to convene such meetings.

\section{Conclusion}

The analysis took place in a context characterised by limited opportunities for "over the fence" diffusion of innovations related to dairy farming and very limited presence of institutions outside the community to support this activity. Both elements underline the importance of farmer-to-farmer discussion networks to improve cattle farming practices. In this context, our analysis revealed two contrasted cases concerning the question of whether cooperatives were a space for farmer-to-farmer communication and learning. In cooperative B, the compound was an important space for discussion about dairy farming, but membership of the cooperative only slightly overlapped involvement in dialogue networks and the cooperative was not involved in improving dairy techniques. In contrast, cooperative A was a space for peer-to-peer discussion and learning, not so much a physical space, but because: i) farmers mostly talked to fellow members of the cooperative; ii) some key members of the management committee played a major role in providing advice about dairy farming, albeit not on all subjects related to cattle farming, and iii) the cooperative was involved in actions to improve dairy farming.

The study investigated only two cooperatives, which are obviously not representative of the range of possible situations of local farmers' organisations. In particular, the performance of collective action is not necessarily correlated with the vitality of the discussion networks. However, the two case studies represented contrasted situations regarding stumbling blocks and opportunities to involve local farmers' organisations in capacity building. In the case of cooperative B, before looking for involvement in capacity building on the part of the cooperative, external support should first consider possible ways to assist collective action at cooperative or community level. In contrast, in cooperative A, discussion networks were well framed by the cooperative, which provided active support for dairy farming, even if support was limited to certain innovations. Cooperative A appeared to be an appropriate partner for capacity building.

In developing countries, smallholder farmers' organisations, which are often set up for service provision, could thus be valuable partners to take into account local networks for knowledge communication in capacity-building activities. In order to benefit from such opportunities, it may be useful to develop methods that are simpler to implement than the one described in this paper to make initial assessments of the way dialogue networks are framed in farmers' organisations, and of the performance of collective action at cooperative level.

Finally, the analysis showed the two-way interaction between the performance of collective action and the structure of local discussion networks, and argued that well-functioning local farmer organisations may play a role in improving the efficiency of such networks. The link between collective action and discussion networks could also be investigated the other way around, i.e., further research may look at to what extent supporting discussion networks regarding farming practices may provide ground for improved collective action, especially within local farmer organisations.

\section{Acknowledgments}

The study was carried out in the framework of the SIRMA project, financed by the French Ministry of Foreign and European Affairs. The authors thank the farmers for their availability during the survey and the cooperatives for their active support in implementing it. A. Layadi, A. Ben Hammi and M. El Mokhtar participated in carrying out the survey. The authors wish to thank two anonymous reviewers for their helpful comments and suggestions.

\section{References}


Borgatti, S. P. (2002) NetDraw: Graph Visualization Software. Harvard: Analytic Technologies.

Borgatti, S. P. \& Everett, M.G. (1999) Models of Core/Periphery Structures. Social Networks, 21, pp. 375-395.

Callon, M. (1986) Some Elements of a Sociology of Translation: Domestication of the Scallops and Fishermen of St. Brieuc Bay, in: Law J. (Ed) Power, Action and Belief: a New Sociology of Knowledge? London: Routledge, pp. 196-233.

Chiffoleau, Y. (2005) Learning about Innovation Through Networks: the Development of Environment-friendly Viticulture. Technovation, 25, pp. 1193-204.

Cristóvão, A. \& Pereira, F. (2004) Portugal: Extension Reform in the interior North of Portugal. In: Riveira, W. and Alex, G. (Eds) Volume 3. Demand-Driven Approaches to Agriculture Extension. Case Studies of International Initiatives. Washington, D.C.: World Bank, pp. 96103.

Crona, B. \& Bodin, O. (2006) What You Know is Who You Know? Communication Patterns Among Resource Users as a Prerequisite for Co-management. Ecology and Society, 11(2): 7.

Darr, D. \& Pretzsch, J. (2008) Mechanisms of Innovation Diffusion Under Information Abundance and Information Scarcity. The Contribution of Social Networks in Groups vs. Individual Extension Approaches in Semi-arid Kenya. The Journal of Agricultural Education and Extension, 14(3), pp. 231-248.

Darré, J.P. (1991). Les Hommes Sont des Réseaux Pensants. Sociétés Contemporaines, 5, pp. 55-66.

Darré, J.P. (1996). L'Invention Des Pratiques Dans l'Agriculture. Vulgarisation et Production Locale de Connaissance. Paris: Karthala.

Diani, M. \& McAdam, D. (Eds) (2003) Social Movements and Networks. Relational Approaches to Collective Action. Oxford: Oxford University Press.

Eklund, P., Imai, K. \& Felloni, F. (2007) Women's Organisations, Maternal Knowledge and Social Capital to Reduce Prevalence of Stunted Children: Evidence from Rural Nepal. Journal of Development Studies, 43(3), pp. 456-489.

Faysse, N., Errahj, M., Kuper, M. \& Mahdi, M. (2010) Learning to Voice? The Evolving Roles of Family Farmers in the Coordination of Large-scale Irrigation Schemes in Morocco. Water Alternatives, 3(1), pp. 48-67.

Granovetter, M. (1973). The Strength of Weak Ties. The American Journal of Sociology, 78, pp. $1360-1380$.

Hall, A. (2009) Challenges to Strengthening Agricultural Innovation Systems: Where Do We Go From Here? in: Scoones, I. and Thompson, J. (Eds) Farmer First Revisited. Innovation for Agricultural Research and Development. Rugby: Practical Action Publishing, pp. 30-38.

Heemskerk, W., Nederlof, S. \& Wennink, B. (2008) Outsourcing Agricultural Advisory Services. Enhancing rural innovation in sub-Saharan Africa. Bulletin $\mathrm{n}^{\circ}$ 38. Amsterdam: KIT Publishers.

Hoang, L.A., Castella, J.C. \& Novosad, P. (2006) Social Networks and Information Access: Implications for Agricultural Extension in a Rice Farming Community in Northern Vietnam. Agriculture and Human Values, 23(4), pp. 513-527.

Isaac, M. E., Erickson, B.H., Quashie-Sam, S. \& Timmer, V.R. (2007) Transfer of Knowledge on Agroforestry Management Practices: the Structure of Farmer Advice Networks. Ecology and Society, 12(2): 32.

Khlifi, S. (2008) Analyse des Facteurs de Variation de la Production Laitière chez des Eleveurs de Coopératives Laitières dans le Gharb et le Loukkos. Master Thesis. Meknes: Ecole Nationale d'Agriculture.

Layadi, A., Faysse, N., Errahj, M. \& Sraïri, M.T. (Forthcoming) Renforcer le Dialogue Technique: Partenariat avec une Organisation Professionnelle Agricole Locale pour l'Amélioration de l'Elevage Bovin au Maroc. Cahiers Agricultures.

Leeuwis, C. \& Van den Ban, A. (2004) Communication for Rural Innovation. Rethinking Agricultural extension. Oxford: Blackwell Science.

Marshall, G. (1998) A Dictionary of Sociology. New York: Oxford University Press.

Matuschke, I. (2008) Evaluating the Impact of Social Networks in Rural Innovation Systems: An Overview. Washington, D.C.: International Food Policy Research Institute. 
Meinzen-Dick, R., Di Gregorio, M., \& McCarthy, N. (2004).Methods for Studying Collective Action in Rural Development. Agricultural Systems, 82(3), pp. 197-214.

Mercoiret, M.R., Pesche, D. \& Bosc, P.M. (2006) Rural Producer Organizations for Pro-poor Sustainable Development. Washington, D.C.: World Bank.

Moumouni, I.M., Vodouhe, S.D. \& Streiffele, D. (2009). What Makes Small-Scale Farmers Participate in Financing Agricultural Research and Extension? Analysis of Three Case Studies from Benin. Journal of Agricultural Education and Extension, 15(3), pp. 301-316.

Perez, S.A., Tegbaru, A. Kantengwa, S. \& Farrow, A. (2009) Village Information and Communication Centres in Rwanda. In: Sanginga, P., Waters-Bayer, A., Kaaria, S., Njuki, J. and Wettansinha, C. (Eds) Innovation Africa. Enriching farmers' livelihoods. London: Earthscan.

Pomp, M. \& Burger, K. (1995) Innovation and Imitation: Adoption of Cocoa by Indonesia Smallholders. World Development, 23(3), pp. 423-431.

Pretty, J. \& Ward, H. (2001) Social Capital and Environment. World Development, 29(2), pp. 209227.

Rogers, E.M. (1995) Diffusion of Innovations. New York: Free Press.

Sanginga, P.C., Tumwine, J. \& Lilja, N.K. (2006) Patterns of Participation in Farmers' Research Groups: Lessons from the Highlands of Southwestern Uganda. Agricultural and Human Values, 23: pp. 501-512.

Sanginga, P.C., Waters-Bayer, A., Kaaria, S., Njuki, J. \& Wettasinha, C. (2009) Innovation Africa. Enriching Farmers' Livelihoods. London: Earthscan.

Saurabh, A. (2009) Knowledge Flows and Social Capital. A network perspective on rural innovation. $\mathrm{PhD}$ thesis, Maastricht University.

Scoones, I. \& Thompson, J. (2009) Farmer First Revisited: Innovation for Agricultural Research and Development. In: Scoones, I. and Thompson, J. (Eds) Farmer First Revisited. Innovation for Agricultural Research and Development. Rugby: Practical Action Publishing, pp. 3-38.

Shah, T. (1996) Catalysing Co-operation. Design of Self-Governing Organisations. New Delhi: Sage.

Sraïri, M.T., Kiade, N., Lyoubi, R., Messad, S. \& Faye, B. (2009) A Comparison of Dairy Cattle Systems in an Irrigated Perimeter and in a Suburban Region: Case Study from Morocco. Tropical Animal Health and Production, 41, pp. 259-272.

Tin, H.Q., Struik, P.C., Price, L.L., Tuyen, N.P., Hoan, N.P. \& Bos. H. (2010) Increase of Farmers' Knowledge through Farmer Seed Production Schools in Vietnam as Assessed on the Basis of Ex-ante and Ex-post Tests. Journal of Agricultural Education and Extension, 16 (3), pp. 229247.

Valente, T.W. (1996). Social Network Thresholds in the Diffusion of Innovations. Social Networks, 18: pp. 69-89.

Van Der Broeck, K. \& Dercon, S. (2007) Information Flows and Social Externalities in a Tanzanian Banana Growing Village. Journal of Development Studies, 47(2): pp. 231 - 252.

Wasserman, S. \& Faust, K. (1994) Social Network Analysis: Methods and Application. Cambridge: Cambridge University Press.

Wennink, B. \& Heemskerck, W. (2006) Farmers' Organizations and Agricultural Innovation. Bulletin $\mathrm{n}^{\circ}$ 374. Amsterdam: KIT Publishers.

Wyckhuys, K.A.G \& O'Neil, R.J. (2007) Role of Opinion Leadership, Social Connectedness and Information Sources in the Diffusion of IPM in Honduran Subsistence Maize Agriculture. International Journal of Pest Management, 53(1): 35-44. 